Article

\title{
Changes in Gel Structure and Chemical Interactions of Hypophthalmichthys molitrix Surimi Gels: Effect of Setting Process and Different Starch Addition
}

\author{
Xin Jiang ${ }^{1}$, Qing Chen ${ }^{1}$, Naiyong Xiao ${ }^{1}$, Yufan Du ${ }^{1}$, Qian Feng ${ }^{1}$ and Wenzheng Shi ${ }^{1,2, *}$ \\ 1 College of Food Sciences \& Technology, Shanghai Ocean University, Shanghai 201306, China; \\ 13053523375@163.com (X.J.); talina_chen@126.com (Q.C.); Xny931215@163.com (N.X.); \\ yfdu122433@163.com (Y.D.); 18361206059@163.com (Q.F.) \\ 2 National Research and Development Center for Processing Technology of Freshwater Aquatic \\ Products (Shanghai), Shanghai 201306, China \\ * Correspondence: wzshi@shou.edu.cn; Tel.: +86-156-9216-5859
}

check for updates

Citation: Jiang, X.; Chen, Q.; Xiao, N.; Du, Y.; Feng, Q.; Shi, W. Changes in Gel Structure and Chemical Interactions of Hypophthalmichthys molitrix Surimi Gels: Effect of Setting Process and Different Starch

Addition. Foods 2022, 11, 9. https:// doi.org/10.3390/foods11010009

Academic Editors: Jianhua Xie, Yanjun Zhang and Hansong Yu

Received: 22 November 2021

Accepted: 15 December 2021

Published: 21 December 2021

Publisher's Note: MDPI stays neutral with regard to jurisdictional claims in published maps and institutional affiliations.

Copyright: (C) 2021 by the authors. Licensee MDPI, Basel, Switzerland. This article is an open access article distributed under the terms and conditions of the Creative Commons Attribution (CC BY) license (https:// creativecommons.org/licenses/by/ $4.0 /)$.

\begin{abstract}
The modifications of histological properties and chemical forces on heated surimi gels with starch addition (0-12 g/100 g surimi) were investigated. Two types of heating processes (direct heating and two-step heating) were carried out on surimi gels in order to reveal the effect of setting on mixed matrices. The results of transverse relaxation time showed less immobile water and free water converted into bound water in a matrix subjected to the setting process. Scanning electron microscope and light microscopy images revealed inefficient starch-swelling in two-step heated gels. Chemical interactions and forces in direct cooking gels were more vulnerable to starch addition, resulting in significant decreases in hydrophobic interaction and sulfhydryl content $(p<0.05)$. With the increment of starch, the disulfide stretching vibrations of the gauche-gauche-gauche conformation were reduced in both gel matrices. The structural variations of different components collectively resulted in changes in texture profile analysis and water holding capacity. Overall, the results demonstrated that starch addition had a great and positive effect on the weak gel matrix by direct heating.
\end{abstract}

Keywords: surimi; starch; setting; water migration; microstructure; chemical interactions

\section{Introduction}

Surimi-based products have become an increasingly consumed food with prominent characteristics of convenience, special flavor, and unique texture [1]. In addition, the deep processing technology gave it the qualities of excellent nutritional value and high digestibility [2]. Due to the continuous overexploitation of marine fishing resources, lowvalue or cultured fish has been paid more attention as a potential alternative raw material for surimi production [3]. Silver carp (Hypophthalmichthys molitrix), widely cultured in China, is considered a low-commercial value fish due to its muddy flavor and higher by-product content [4]. However, due to its rapid growth, high yield, and low price, silver carp could replace sea fish as raw material for surimi [5]. Through the processes of rinsing, dehydration, and defatting, the myofibrillar protein could be well retained, and more fishy compounds were removed, which improved the flavor characteristics to a certain extent. Raw surimi could be further processed into prepared foods or ready-to-eat foods in order to satisfy different taste demands for surimi-based products, which realize the value addition of silver carp [6].

Throughout the entire process of thermal gel formation, heat treatment is an important step in determining the quality of the gel matrix [7]. Before heating, free myosin molecules and actomyosin complexes were dispersed, while the network structure complex reinforced by actomyosin was completed as the temperature rose [8]. Based on the unique property of fish protein, heating processes can be divided into direct heating and two-step heating, with significant differences in protein networks between these two treatments [9]. Direct 
heating treatment provided the gel with soft structure but might cause the formation of protein aggregates in different sizes [10]. In case of two-step heating, an extension of setting time at $4-40{ }^{\circ} \mathrm{C}$ prior to heating at $90{ }^{\circ} \mathrm{C}$ could strengthen gel properties, which was widely used in making kamaboko [6]. The first setting step, in which more available cross-linking sites become accessible, ensured a gradual sol-gel transition so that an orderly initial protein network formed [11,12]. Subsequent secondary heating at high temperature is used for the final production of thermal gels [13]. Compared with direct heated gels, the two-step heated gels enabled the gel structure to remain more compact even when suffering from physical forces [10]. Hence, the setting process played a vital role in gel processing. However, the addition of some exogenous substances during the actual processing was also necessarily for helping improve gel texture.

Starch, as a popular food additive for improving gels, plays an essential role in reducing the factory processing costs of surimi-based products and meeting consumer taste needs [14,15]. According to the "packing effect" raised by Kong et al. [16], the starch granules swelled and then exerted more pressure on the gel matrix, forming a firm and cohesive gel. Starch swelling in the surimi matrix increased the hardness of the gels, thereby improving overall gel properties. It also found that starch did not crosslink with the surimi protein, whereas it could change the chemical interaction in the surimi matrix [17]. Thus far, studies have mainly emphasized the effects of different starches in improving gel strength [17-19]. Nevertheless, the surimi gel network also affected the filling effect of starch in the mixture, which was rarely reported in research. It was hypothesized that the characteristics of the starch-containing surimi matrix could be affected by the setting processing, showing different change trends in various properties. Accordingly, two heating processes (direct heating process and two-step heating process) were set up to detect the different properties of the mixed matrix and to compare the systematic effect of the setting process on the heated starch-surimi matrix.

Therefore, the research aimed to elucidate water migration, microstructure, chemical interactions, and surimi protein structure in the starch-surimi matrix comprehensively. Physical properties, such as texture profile analysis, whiteness, and water holding capacity, were also detected, providing insight into the combined effect of thermal processing and exogenous additives on texture characteristics.

\section{Materials and Methods}

\subsection{Materials and Reagents}

Silver carp frozen surimi (AAA grade, cryoprotectants were $6 \%$ sucrose and $0.25 \%$ polyphosphate) obtained from Jinli Fishery Food Co., Ltd. (Honghu, China) was cut into pieces weighing about $200 \mathrm{~g}$ and stored at $-20^{\circ} \mathrm{C}$ after vacuum sealing. The moisture and crude protein contents were $75.20 \%$ and $14.37 \%$, respectively. Native potato starch was purchased from Hangzhou Starpro Starch Co., Ltd. (Hangzhou, China). The P0006C Detergent Compatible Bradford Protein Assay Kit was obtained from Shanghai Beyotime Biotechnology Co., Ltd. (Shanghai, China). The other chemicals were analytical grade, with the exception of $\mathrm{KBr}$ (spectrography), and purchased from Sinopharm Chemical Reagent Co., Ltd. (Shanghai, China).

\subsection{Sample Preparation}

Frozen surimi was thawed at $4{ }^{\circ} \mathrm{C}$ overnight and cut into small pieces. An amount of $200 \mathrm{~g}$ of semi-thawed silver carp surimi was blended for $2 \mathrm{~min}$ and then mixed with $5 \mathrm{~g}$ of $\mathrm{NaCl}$ for $4 \mathrm{~min}$. During the blending process, moisture content was adjusted to $80 \%$ with iced water that was also used to keep the temperature of mixtures below $10{ }^{\circ} \mathrm{C}$. Native potato starch $(0 \mathrm{~g}, 3 \mathrm{~g}, 6 \mathrm{~g}, 9 \mathrm{~g}$, or $12 \mathrm{~g} / 100 \mathrm{~g}$ surimi) was added to the surimi and mixed in blender (AM-CG108-1, Appliance Co. of America, Zhuhai, China) for $6 \mathrm{~min}$. Then, starch-surimi combinations were filled into the plastic tubes with a diameter of $25 \mathrm{~mm}$ and heated in two different processes. In the direct heating process, the tubes were heated in a water bath at $90^{\circ} \mathrm{C}$ for $30 \mathrm{~min}$, obtaining cooking gel (CG). In the two-step heating process, 
a combination of preheating at $40^{\circ} \mathrm{C}$ for $1 \mathrm{~h}$ and cooking at $90^{\circ} \mathrm{C}$ for $30 \mathrm{~min}$ was carried out to obtain setting-cooking gel (SCG) [6]. After heating, all samples were stored at $4{ }^{\circ} \mathrm{C}$ for $12 \mathrm{~h}$.

\subsection{Low Field Nuclear Magnetic Resonance (LF-NMR)}

The relaxation time and moisture distribution were measured by a Niumag Pulsed NMR analyzer (MesoMR23-060H-I, Niumag Electric Co., Shanghai, China). Gel samples were cut into the cylinders with a height of $20 \mathrm{~mm}$, and a CPMG (Carr-Purcell-MeiboomGill) pulse sequence was carried out $[20,21]$. The CPMG parameters are listed in Table 1.

Table 1. CPMG parameters.

\begin{tabular}{llllccccccccc}
\hline CPMG & SF & SW & RFD & Tw & RG1 & DRG1 & PRG & P1 & P2 & TE & NECH & NS \\
\hline Parameter & 21 & 200 & 0.08 & 2500 & 10 & 3 & 1 & 20 & 40 & 0.3 & 8000 & 8 \\
\hline
\end{tabular}

SF: magnet frequency, MHz; SW: spectral width, kHz; RFD: radio frequency delay, ms; Tw: recycle delay, ms; RG1: regulate analog gain 1, db; DRG1: regulate digital gain 1; PRG: pre-amplified receiver gain; $\mathrm{P1}: 90^{\circ}$ pulse lengths, $\mu \mathrm{s} ; \mathrm{P} 2: 180^{\circ}$ pulse lengths, $\mu \mathrm{s}$; TE: pulse gaps between $\pi$ and $\pi$, ms; NECH: echo number; NS: scanning number.

\subsection{Scanning Electron Microscope (SEM)}

The surimi gels were cut into $3 \mathrm{~mm} \times 3 \mathrm{~mm} \times 1.5 \mathrm{~mm}$ pieces and fixed with glutaraldehyde $(2.5 \%, v / v)$ for $14 \mathrm{~h}$ at $4{ }^{\circ} \mathrm{C}$. The fixed samples were rinsed with $0.1 \mathrm{M}$ phosphoric acid buffer ( $\mathrm{pH} 7.2-7.4$ ) three times. After that, the samples were dehydrated with a serious of ethanol solution $(30 \%, 50 \%, 70 \%, 80 \%, 90 \%$, and 100\%) and then replaced with tert-butanol solution (absolute ethanol: tert-butanol = 3:1, 1:1, 1:3, 0:1). The dehydrated samples were dried by using a freeze dryer (SCIENTZ-10N, Ningbo Scientz Biotechnology Co., Ltd., Ningbo, China) and sputter-coated with gold. The microstructures were analyzed by an SEM instrument (Hitachi SU5000, Hitachi High-Tech Co., Ltd., Shanghai, China) at an acceleration voltage of $5 \mathrm{kV}$.

\subsection{Light Microscopy (LM)}

Surimi gels were cut into $5 \mathrm{~mm}$ cubes and immersed with $10 \%$ formalin fixture solution $(1: 10, w / v)$ for more than $24 \mathrm{~h}$. After being dehydrated with gradient alcohol $(75 \%, 85 \%$, $90 \%, 95 \%$, and $100 \%$ ), the samples were placed in xylene followed by wax leaching using an embedding machine (JB-P5, Wuhan Junjie Electronics Co., Ltd., Wuhan, China). After cooling at $-20^{\circ} \mathrm{C}$, the paraffin slice was cut with a thickness of $4 \mu \mathrm{m}$ carried out by a tissue spreader (KD-P, Zhejiang Kehua Instrument Co., Ltd., Jinhua, China). The dewaxed slices were stained using the periodic acid-Schiff (PAS) method according to the method of Jia et al. [22]. The samples were observed using a light microscope (MS500W, Shanghai Meizs Precision Instrument Co., Ltd., Shanghai, China).

\subsection{Determination of Non-Covalent Bonds}

The chemical interactions or bonds were determined according to the method of Yan et al. [23] with slight modifications. Briefly, $1 \mathrm{~g}$ of surimi gels was added $10 \mathrm{~mL} 0.05 \mathrm{M}$ $\mathrm{NaCl}(\mathrm{A}), 0.6 \mathrm{M} \mathrm{NaCl}(\mathrm{B}), 0.6 \mathrm{M} \mathrm{NaCl}+1.5 \mathrm{M}$ urea (C), and $0.6 \mathrm{M} \mathrm{NaCl}+8 \mathrm{M}$ urea (D) and homogenized for 2 min by homogenizer (Shanghai Fokker Equipment Co. Ltd., Shanghai, China). The mixtures were placed at $4^{\circ} \mathrm{C}$ for $1 \mathrm{~h}$ and subsequently centrifuged at $15,000 \times$ $g$ for $10 \mathrm{~min}$ by refrigerated centrifuge (CR21GШ, Hitachi High-Tech Co., Ltd., Shanghai, China).

The protein concentrations of supernatant collected were determined by using the Biuret method [24]. The contents of nonspecific associations (A), ionic bonds (B), hydrogen bonds (C), and hydrophobic interactions (D) were determined by the concentrations of soluble protein in supernatants. 


\subsection{Determination of Total Sulfhydryl Groups}

The measurement of total SH content was described by Zhang et al. [25]. According to the following equation, the content of $\mathrm{SH}$ was calculated.

$$
\mathrm{SH} \text { groups } \mu \mathrm{mol} / \mathrm{g} \text { protein }=\frac{\mathrm{A} \times \mathrm{D}}{\varepsilon \times \mathrm{d} \times \mathrm{c}} \times 10^{6}
$$

In the equation, $\mathrm{A}$ and $\mathrm{D}$ represent absorbance at $412 \mathrm{~nm}$ and the dilution ratio, respectively; $\varepsilon$ refers to molar extinction coefficient, $13,600 \mathrm{~L} /(\mathrm{mol} \cdot \mathrm{cm}) ; \mathrm{d}$ is the thickness of cuvette, $1 \mathrm{~cm}$; and $\mathrm{c}$ is the protein concentration, $4 \mathrm{mg} / \mathrm{mL}$.

\subsection{Fourier Transform Infrared (FT-IR) Spectroscopy}

The surimi gels were freeze-dried and ground into powder. An amount of $1.5 \mathrm{mg}$ of powder was mixed with $150 \mathrm{mg} \mathrm{KBr}$ and then pressed into a transparent sheet. The spectrums of the matrix were observed by a Nicolet iS5 FT-IR spectrometer (Thermo Fisher Instruments Co., Ltd., Shanghai, China). Samples were then scanned 32 times from 400 to $4000 \mathrm{~cm}^{-1}$ with a resolution of $4 \mathrm{~cm}^{-1}$ [26]. Relative intensity was analyzed by OMNIC 9.2 software (Thermo Fisher Scientific Inc., Waltham, MA, USA) and PeakFit 4.12 software (Systat Software Inc., San Jose, CA, USA).

\subsection{Texture Profile Analysis (TPA)}

Equilibrium temperature to $25{ }^{\circ} \mathrm{C}$, the gel matrix was cut into cylinders $(20 \mathrm{~mm} \times$ $20 \mathrm{~mm}$ ), and TPA was determined by using a TA-XT Plus texture analyzer (Stable Micro Systems Ltd., Godalming, UK) with P/50 cylindrical probe. The pre-test speed and test speed were both $1 \mathrm{~mm} \cdot \mathrm{s}^{-1}$, the compression percentage was $40 \%$, and the trigger force was $5 \mathrm{~g}$.

\subsection{Determination of Whiteness}

The surimi gels were cut with a thickness of $10 \mathrm{~mm}$. The L* (lightness), a* (redness/greenness), and $b^{*}$ (yellowness/blueness) values of gels were determined by colorimeter (CR-400, Konica Minolta Japan, Inc., Tokyo, Japan). Whiteness was calculated as follows.

$$
\text { Whiteness }=100-\left[\left(100-\mathrm{L}^{*}\right)^{2}+\mathrm{a}^{* 2}+\mathrm{b}^{* 2}\right]^{1 / 2}
$$

\subsection{Determination of Water Holding Capacity (WHC)}

All samples were cut into $3 \mathrm{~g}$ with a thickness of about $5 \mathrm{~mm}$, weighed $\left(\mathrm{W}_{1}\right)$ and then placed into three layers of filter paper. After centrifugation of $15 \mathrm{~min}\left(5000 \times g, 4{ }^{\circ} \mathrm{C}\right)$, the gels were quickly weighed again $\left(\mathrm{W}_{2}\right)$. The equation of water holding capacity is defined as follows:

$$
\begin{gathered}
\text { Centrifugal loss }(\%)=\frac{\mathrm{W}_{2}}{\mathrm{~W}_{1}} \times 100 \\
\text { Water holding capacity }(\%)=\frac{\mathrm{M}-\mathrm{CL}}{\mathrm{M}} \times 100
\end{gathered}
$$

where CL is the centrifugal loss of surimi gel after heating, and $\mathrm{M}$ is the moisture content determined by drying the sample at $105^{\circ} \mathrm{C}$ until constant weight.

\subsection{Statistical Analysis}

All experiments were performed at least three times, and the results were presented as the mean \pm standard deviation (SD). Statistical Package for Social Science (SPSS 26, SPSS Inc., Chicago, IL, USA) was used to carry out all statistical analysis with the significance level set at 0.05 based on one-way analyses of variance (ANOVA). Significant differences were evaluated by Duncan's multiple range test $(p<0.05)$. 


\section{Results and Discussion}

\subsection{Changes of Relaxation Time and Water Distribution of Starch-Surimi Gels with Non-Setting or Setting Effect}

The results of LF-NMR can effectively determine water mobility and distribution in gel matrix [27]. $\mathrm{T}_{2 \mathrm{~b}}(1-20 \mathrm{~ms}), \mathrm{T}_{21}(20-300 \mathrm{~ms})$, and $\mathrm{T}_{22}(400-2000 \mathrm{~ms})$ represented the transverse relaxation time of bound water, immobilized water, and free water (Figure 1a, b), respectively. It was obvious the relaxation time of different water migrated. As shown in Figure $1 \mathrm{c}, \mathrm{d}$, the peak relaxation time of bound water $\left(\mathrm{T}_{\mathrm{P} 2 \mathrm{~b}}\right)$ in gels without starch was 2.39 $\mathrm{ms}(\mathrm{CG})$ and $1.94 \mathrm{~ms}(\mathrm{SCG})$, between which there was a significant difference $(p<0.05)$ that might be related to the gel structure heated by dissimilar processes. $\mathrm{T}_{\mathrm{P} 2 \mathrm{~b}}$ increased by starch addition and showed a positive correlation with starch content. The migration of $\mathrm{T}_{\mathrm{P} 2 \mathrm{~b}} \mathrm{was}$ relevant to different water mobility bound by the protein and starch. The peak relaxation time of immobile water $\left(\mathrm{T}_{\mathrm{P} 21}\right)$ dropped from $101.71 \mathrm{~ms}$ to $71.71 \mathrm{~ms}$ in CG, and from 94.84 $\mathrm{ms}$ to $65.36 \mathrm{~ms}$ in SCG. The shorter the relaxation time $\left(\mathrm{T}_{2}\right)$, the stronger the binding force of water molecules to matrix [12]. Thus, the water mobility of bound water significantly increased with starch incorporation $(p<0.05)$, while the mobility of non-mobile and free water decreased in both matrices. This was consistent with the investigation by Li et al. [28], who found that starch showed a better restriction capacity on the free motion of water molecules. However, the relaxation time between the two types of gels had a significant difference $(p<0.05)$, indicating that starch-swelling differed in gel matrices with different heating treatments.

(a)

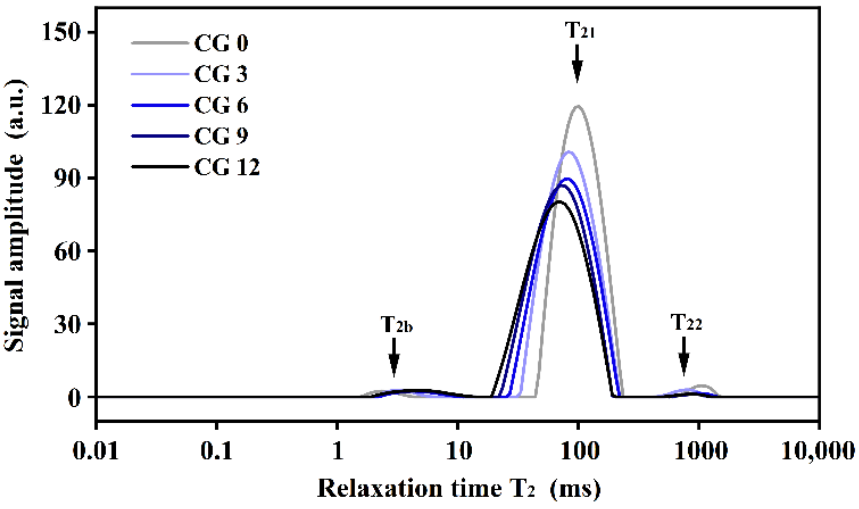

(c)

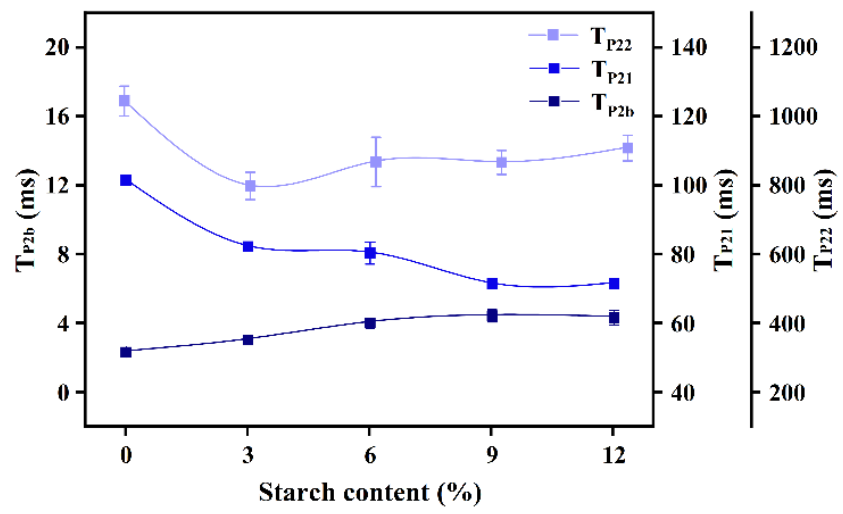

(b)

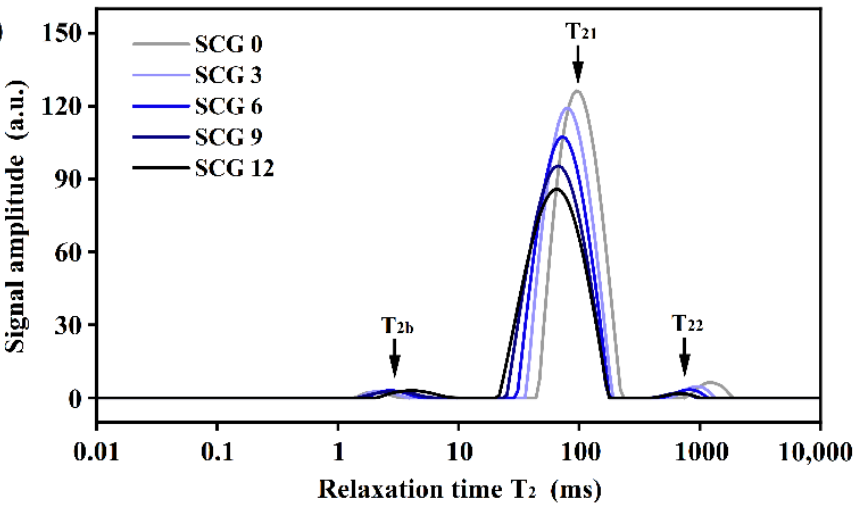

(d)

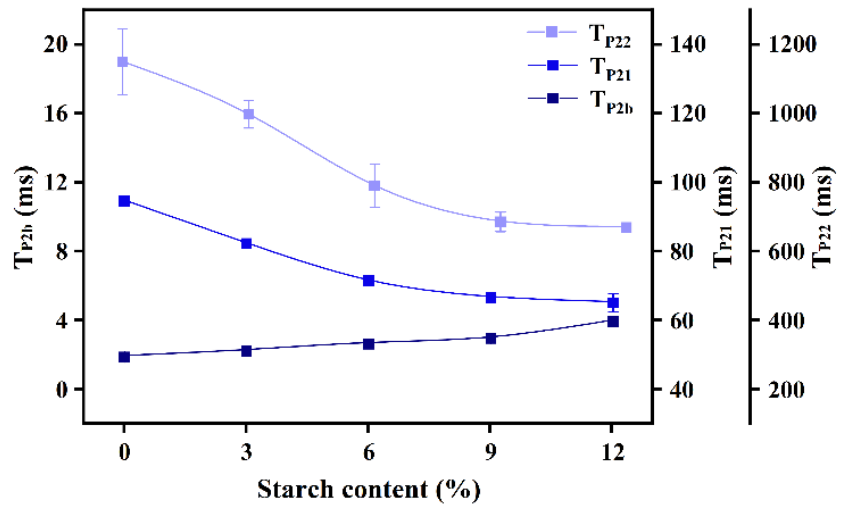

Figure 1. $T_{2}$ relaxation time $(\mathbf{a}, \mathbf{b})$ and water mobility $(\mathbf{c}, \mathbf{d})$ of starch-surimi matrix in direct heating process and two-step heating process. CG: gel obtained by direct heating; SCG: gel obtained by two-step heating. 0 : without starch; 3, 6, 9, and 12: incorporation with $3 \%, 6 \%, 9 \%$, and $12 \%$ starch.

The relative moisture content was observed by peak area proportions $\left(\mathrm{P}_{\mathrm{T} 2 \mathrm{~b}}, \mathrm{P}_{\mathrm{T} 21}\right.$, and $\mathrm{P}_{\mathrm{T} 22}$ ) in Figure 2. It was discovered that immobile water made up the majority of the primary proportion in surimi gel, followed by bound water and free water. $\mathrm{P}_{\mathrm{T} 21}$ showed 
the relative content of immobile water that increased initially with the addition of starch, resulting in a reduction in free water in both CG and SCG. The $\mathrm{P}_{\mathrm{T} 21}$ of CG and SCG reached a maximum at $6 \%$ and $9 \%$ starch content, respectively. Subsequently, it decreased and was possibly associated with the dehydration of surimi gels suffered by the compression from starch swelling. Moreover, starch incorporation reduced the relative surimi content in the entire matrix, causing a decrease in immobile water content held by surimi gel network. Notably, in the non-starch containing gels, $\mathrm{P}_{\mathrm{T} 21}$ of CG and SCG was $97.20 \%$ and $96.27 \%$, showing that the gel matrix had higher $\mathrm{P}_{\mathrm{T} 21}$ without preincubation at $40{ }^{\circ} \mathrm{C}$. The changes might presumably contribute to overheated time and the squeeze by gel formation in SCG, resulting in a transition from immobile water to free water. Although direct heating formed a poor gel, the juiciness mouthfeel of surimi products improved [29]. Since the hydroxyl groups in starch bound more water, the matrix with starch incorporation significantly differed in $\mathrm{P}_{\mathrm{T} 22}(p<0.05)$. However, $\mathrm{P}_{\mathrm{T} 2 \mathrm{~b}}$ significantly increased with the continuous addition of starch $(p<0.05)$, especially in CG. With $12 \%$ starch, $\mathrm{P}_{\mathrm{T} 2 \mathrm{~b}}$ of CG increased by $173.15 \%$ compared to $113.89 \%$ in SCG. Among the above changes, it indicated that water absorbed by starch existed in the form of immobile water and bound water. Moreover, it was inferred that the starch in direct cooking gels showed better swelling states, which resulted in the phenomena where the internal starch structure tended to easily combine with water.

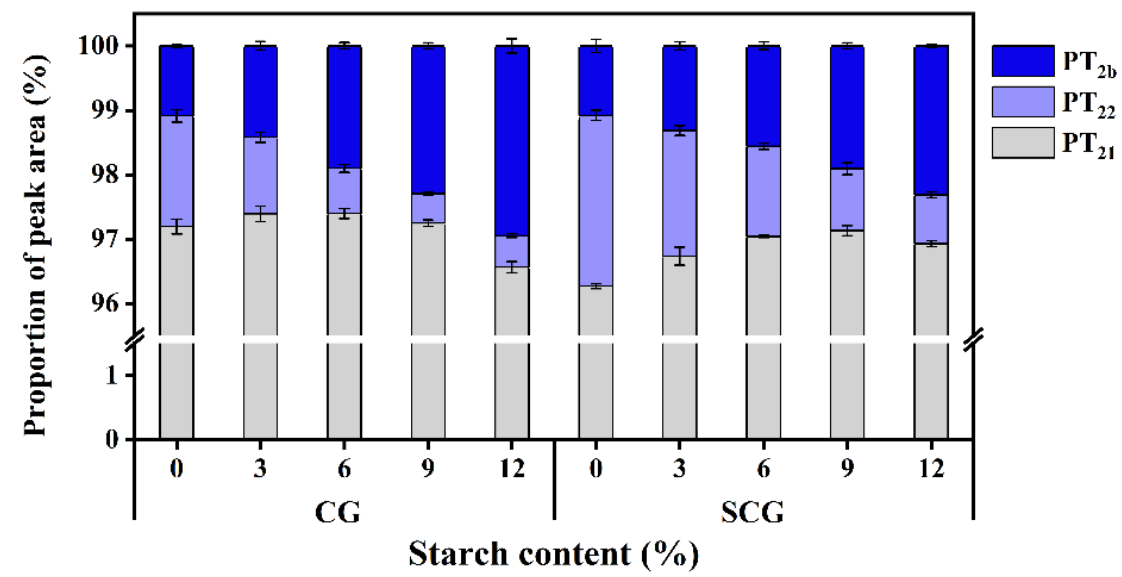

Figure 2. Peak area proportion $\left(\mathrm{P}_{\mathrm{T} 2 \mathrm{~b}}, \mathrm{P}_{\mathrm{T} 21}\right.$, and $\left.\mathrm{P}_{\mathrm{T} 22}\right)$ of different water in starch-surimi matrix subjected to direct heating and two-step heating. Caption: see Figure 1.

\subsection{Changes in Tissue Histology of Starch-Surimi Gels with Non-Setting or Setting Effect \\ 3.2.1. Light Micrograph}

The morphology of potato starch differed appreciably between direct heated gels and two-step heated gels (Figure 3). It was observed that a nearly spherical morphology of starch was shown in SCG, whereas a relatively irregular state was observed in CG. Starch showed non-obstructive expansion in CG with $3 \%$ or $6 \%$ starch content. The striation structures inside of starch granules were intact with an increase in starch content, showing that the swelling degree of starch decreased in CG. In comparison, it was observed that potato starch granules in SCG were almost circular, especially in the low starch-containing matrices. In addition, large granule starch could not realize valuable swelling in two-step heating. However, regardless of non-setting or setting samples, small starch granules showed extended states, which was more conducive for applying starch in the surimi matrix. 


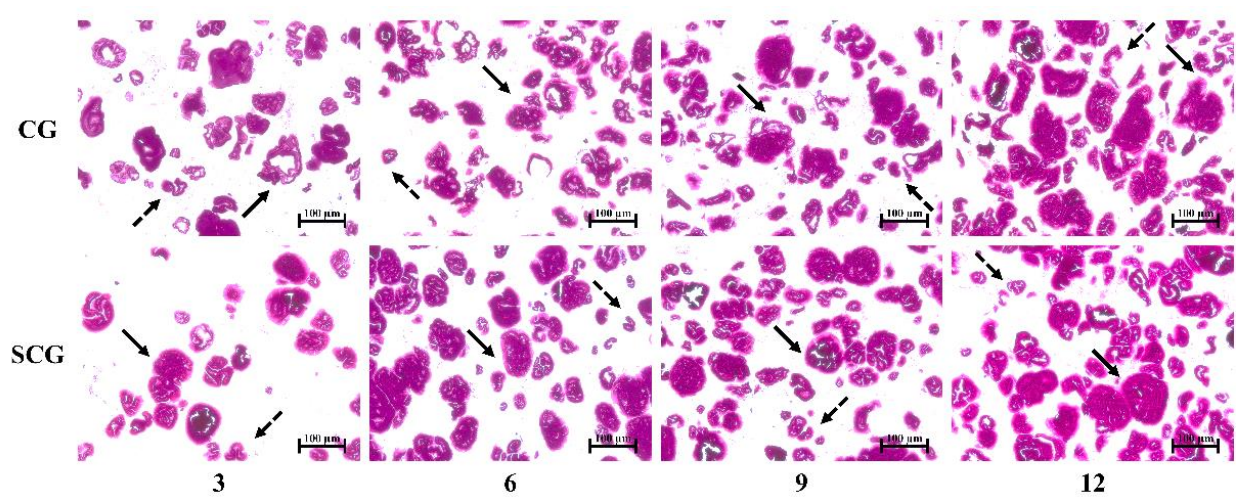

Figure 3. Light microscopy of cooking gels and setting-cooking gels at four starch contents $(3 \%, 6 \%$, $9 \%$, and $12 \%$ ). $\nearrow$ indicates large granule starch; $\bar{\nearrow}$ indicates small granule starch. Caption: see Figure 1.

\subsubsection{Scanning Electron Micrograph}

Overall microstructures of starch-surimi gels were observed at $300 \times$ to reflect the morphology of starch and surimi matrix after cooking (Figure 4). The gelatinization temperature of potato starch ranged from 56 to $66^{\circ} \mathrm{C}$, and the amorphous region extended after reaching this temperature range [30]. For CG, as the temperature rose above $45-50{ }^{\circ} \mathrm{C}$, the suwari was partially disrupted, resulting in modori formation and unhindered starch swelling [31]. Moreover, the loose gel network might be a key factor of the irregular swelling of starch. In contrast with non-setting gels, SCG showed more substantial resistance to starch swelling that avoided water loss in the gel network structure. It might contribute to the setting step, which resulted in the formation of a stable surimi gel network in SCG. Thus, it could be determined that the setting effect promoted cross-linking in surimi, hindered water absorption, and broke hydrogen bonds in the striations of starch granules.

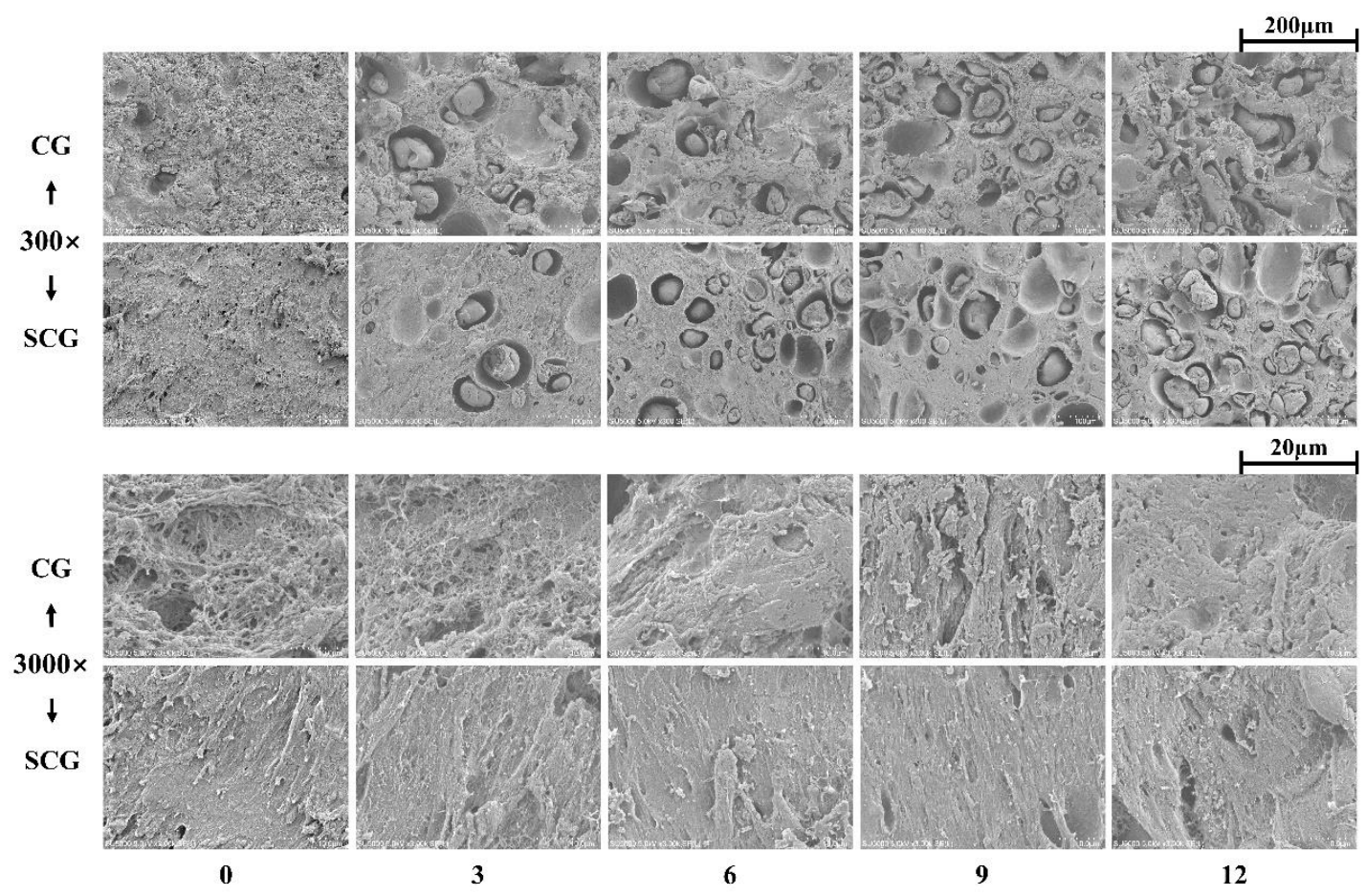

Figure 4. Microstructure micrographs (magnification $\times 300, \times 3000$ ) of starch-surimi matrix subjected with different heating processes: $0,3,6,9$, and 12 represented $0 \%, 3 \%, 6 \%, 9 \%$, and $12 \%$ starch content, respectively. Caption: See Figure 1. 
Viewed at large magnifications, non-starch containing CG exhibited a coarse matrix with large cavities, as shown in Figure 4. However, the addition of the starch made cavities disappear, resulting in more compact surimi. According to the results from Kong et al. [16], these shrunk surimi networks were considered to be responsible for the "packing effect." Meanwhile, for SCG, no significant changes were observed, and smooth structures were shown throughout the addition of starch.

\subsection{Changes in Chemical Interactions of Starch-Surimi Gels with Non-Setting or Setting Effect \\ 3.3.1. Non-Covalent Bonds}

Non-covalent bonds play essential roles in supporting the three-dimensional structure and enhancing gel strength [32]. All of the non-covalent bonds (including the non-specific associations, ionic bonds, hydrogen bonds, and hydrophobic interactions) differed between the two types of heating samples (Table 2). The non-specific associations had significant increases in both CG and SCG $(p<0.05)$ with the increase in starch content, which resulted from a weak link with low molecular proteins in the gel [33]. Li et al. [28] discovered that the non-specific associations of myofibrillar protein were affected by starch with a larger particle size. Hence, the increase in non-specific associations might be attributed to the expansion of potato starch. The ionic bonds generated by electrostatic interactions between peptides also increased [34]. Hydrogen bonds could enhance the rigidity of the gel, but it might be easily destroyed under high temperature. However, the reduction in hydrogen bonds, in turn, allowed the hydration of exposed peptide backbones and, thus, was important in stabilizing bound water [2]. Overall, these weak forces uniformly increased with the increment of starch content, containing non-specific associations, ionic bonds, and hydrogen bonds $(p<0.05)$.

Table 2. Non-covalent bonds and total sulfhydryl groups of starch-surimi mixtures subjected with different heating processes.

\begin{tabular}{ccccccc}
\hline \multirow{2}{*}{ Samples } & $\begin{array}{c}\text { Starch } \\
\text { Content (\%) }\end{array}$ & $\begin{array}{c}\text { Non-Specific } \\
\text { Associations }\end{array}$ & Ionic Bonds & $\begin{array}{c}\text { Hydrogen } \\
\text { Bonds }\end{array}$ & $\begin{array}{c}\text { Hydrophobic } \\
\text { Interactions }\end{array}$ & $\begin{array}{c}\text { Total Sulfhydryl } \\
\text { Groups } \\
\text { ( } \boldsymbol{\mu m o l / g} \text { Protein) }\end{array}$ \\
\hline & 0 & $0.99 \pm 0.03^{\mathrm{Be}}$ & $0.85 \pm 0.02^{\mathrm{Bd}}$ & $0.39 \pm 0.02^{\mathrm{Bd}}$ & $7.71 \pm 0.35^{\mathrm{Aa}}$ & $25.17 \pm 0.96^{\mathrm{Aa}}$ \\
& 3 & $1.22 \pm 0.01^{\mathrm{Bd}}$ & $1.33 \pm 0.02^{\mathrm{Ac}}$ & $0.63 \pm 0.03^{\mathrm{Bc}}$ & $7.75 \pm 0.27^{\mathrm{Aa}}$ & $20.07 \pm 1.75^{\mathrm{Ab}}$ \\
$\mathrm{CG}$ & 6 & $1.30 \pm 0.02^{\mathrm{Bc}}$ & $1.90 \pm 0.03^{\mathrm{Ab}}$ & $1.21 \pm 0.01^{\mathrm{Bb}}$ & $5.64 \pm 0.10^{\mathrm{Ab}}$ & $19.44 \pm 2.60^{\mathrm{Ab}}$ \\
& 9 & $2.00 \pm 0.01^{\mathrm{Bb}}$ & $1.84 \pm 0.03^{\mathrm{Ab}}$ & $2.19 \pm 0.04^{\mathrm{Aa}}$ & $4.84 \pm 0.10^{\mathrm{Ac}}$ & $18.29 \pm 1.34^{\mathrm{Bb}}$ \\
& 12 & $2.60 \pm 0.06^{\mathrm{Ba}}$ & $2.16 \pm 0.06^{\mathrm{Aa}}$ & $2.21 \pm 0.02^{\mathrm{Ba}}$ & $3.94 \pm 0.10^{\mathrm{Ad}}$ & $12.55 \pm 1.10^{\mathrm{Bc}}$ \\
\hline \multirow{2}{*}{$\mathrm{SCG}$} & 0 & $1.58 \pm 0.05^{\mathrm{Ae}}$ & $1.03 \pm 0.03^{\mathrm{Ad}}$ & $1.16 \pm 0.02^{\mathrm{Ae}}$ & $2.95 \pm 0.09^{\mathrm{Be}}$ & $25.62 \pm 1.91^{\mathrm{Aa}}$ \\
& 3 & $1.97 \pm 0.03^{\mathrm{Ad}}$ & $1.21 \pm 0.02^{\mathrm{Bc}}$ & $1.82 \pm 0.01^{\mathrm{Ad}}$ & $4.06 \pm 0.04^{\mathrm{Ba}}$ & $21.03 \pm 2.02^{\mathrm{Abc}}$ \\
& 6 & $2.43 \pm 0.02^{\mathrm{Ac}}$ & $1.25 \pm 0.03^{\mathrm{Bc}}$ & $2.69 \pm 0.04^{\mathrm{Aa}}$ & $3.47 \pm 0.02^{\mathrm{Bb}}$ & $17.97 \pm 1.75 \mathrm{Ac}$ \\
& 9 & $2.96 \pm 0.04^{\mathrm{Ab}}$ & $1.33 \pm 0.02^{\mathrm{Bb}}$ & $2.19 \pm 0.01^{\mathrm{Ac}}$ & $3.41 \pm 0.03^{\mathrm{Bc}}$ & $23.20 \pm 3.09 \mathrm{Aab}$ \\
& 12 & $4.07 \pm 0.05^{\mathrm{Aa}}$ & $1.56 \pm 0.01^{\mathrm{Ba}}$ & $2.36 \pm 0.03^{\mathrm{Ab}}$ & $3.17 \pm 0.03^{\mathrm{Bd}}$ & $22.43 \pm 1.89^{\mathrm{Aab}}$ \\
\hline
\end{tabular}

Uppercase letters indicate significant difference $(p<0.05)$ between different heating processes, lowercase letters indicate the difference between gels with different starch content $(p<0.05)$, and the values are expressed as mean $\pm \mathrm{SD}$.

Hydrophobic interactions predominate in the gel matrix compared with other noncovalent bonds [17], which are produced by the unfolding action of the protein (above $60^{\circ} \mathrm{C}$ ) and the exposure of the hydrophobic core. With an increase in starch content, hydrophobic interactions declined in CG (Table 2). The unfolding action of the surimi protein structure during heating contributed to the formation of hydrophobic interactions. It could be presumed that the hydrophilic groups absorbed water, resulting in starch swelling as the temperature rose. Subjected to setting treatment, the hydrophobic interactions tended to increase with relatively minor fluctuations. Compared with $C G$, the effect of starch addition on hydrophobic interactions in SCG weakened. This was related to the elastic SCG containing disulfide bonds, which had a high extrusion resistance to starch [35]. 


\subsubsection{Total Sulfhydryl Groups}

Sulfhydryl groups buried in protein are exposed during heating process and subsequently generate disulfide cross-linking [23]. The disulfide bonds display a type of rheological behavior known as rubber elasticity, and they are critical to maintaining network stability [34]. The concentration of total sulfhydryl groups decreased ceaselessly in CG with increased starch content, as shown in Table 2. It was ascribed to internal changes of protein aggregates in which more peptide chains were unfolded and sulfhydryl groups were exposed. Subsequently, the cross-linking of -SH occurred followed by the formation of more disulfide bonds [36]. Nevertheless, faced with stress from starch, SCG showed minor changes in total sulfhydryl groups, contributing to a more stable structure formed by low-temperature preincubation [37].

\subsection{FT-IR Spectroscopy Analysis of Starch-Surimi Gels with Non-Setting or Setting Effect}

3.4.1. Amide Bands of Protein

The gel matrix can be analyzed by using FT-IR spectroscopy to detect functional groups associated with intramolecular and intermolecular structures [38]. The amide bands of proteins have several distinct vibrational modes, including amide I, II, and III. Amide I $\left(1600-1700 \mathrm{~cm}^{-1}\right)$ resulted primarily from $v(\mathrm{C}=\mathrm{O})$ and $\delta(\mathrm{N}-\mathrm{H})$, whereas amide II and III (1480-1580 $\left.\mathrm{cm}^{-1} ; 1200-1350 \mathrm{~cm}^{-1}\right)$ originated from $v(\mathrm{C}-\mathrm{N})$ and $\delta(\mathrm{N}-\mathrm{H})$ [39]. Among them, amide I was the most useful in reflecting secondary and tertiary structures [9]. Generally, the $\alpha$-helix, random coil, $\beta$-sheet, and $\beta$-turn structures correspond to 1650 $1660 \mathrm{~cm}^{-1}, 1660-1665 \mathrm{~cm}^{-1}, 1665-1680 \mathrm{~cm}^{-1}$, and $-1680 \mathrm{~cm}^{-1}$ ranges of the amide I band, respectively [40]. Li et al. [25] discovered that the starch did not cause significant shifts in amide bands (Figure 5a, b, Table 3). Non-setting gels and setting gels both showed peak values of amide I at $1654 \mathrm{~cm}^{-1}$, suggesting that $\alpha$-helix dominated the secondary structure of the protein in the starch-surimi matrix. Although starch could increase the density of the gel matrix and influence chemical interactions, it had little effect on the three-dimensional structure of proteins. In contrast, slight changes in $\alpha$-helix and random coil occurred between CG and SCG, which was conducive to increasing hydrogen bonds. The $\alpha$-helix of native and partially denatured proteins and $\beta$ structures that formed during heating and cooling are both stabilized by hydrogen bonds [2]. Therefore, the secondary structure of surimi protein had no significant change caused by the external physical forces of starch.

Table 3. Secondary structure (amide I) of protein in different starch-surimi matrices.

\begin{tabular}{|c|c|c|c|c|c|}
\hline Samples & Starch Content (\%) & $\alpha$-Helix (\%) & Random Coil (\%) & $\beta$-Sheet (\%) & $\beta$-Turn (\%) \\
\hline \multirow{5}{*}{ CG } & 0 & $26.16 \pm 0.75^{\mathrm{Aa}}$ & $26.49 \pm 0.26^{\mathrm{Aa}}$ & $25.49 \pm 0.18 \mathrm{Aa}$ & $21.85 \pm 0.73 \mathrm{Aa}$ \\
\hline & 3 & $26.89 \pm 1.38$ Ва & $25.80 \pm 1.13 \mathrm{Aa}$ & $25.20 \pm 0.96 \mathrm{Aa}$ & $22.11 \pm 2.84 \mathrm{Aa}$ \\
\hline & 6 & $26.47 \pm 1.07 \mathrm{Aa}$ & $26.03 \pm 0.53 \mathrm{Aa}$ & $25.63 \pm 0.61 \mathrm{Aa}$ & $21.88 \pm 1.02 \mathrm{Aa}$ \\
\hline & 9 & $27.20 \pm 1.01 \mathrm{Ba}$ & $26.00 \pm 0.23 \mathrm{Aa}$ & $25.05 \pm 0.47 \mathrm{Aa}$ & $21.75 \pm 0.35 \mathrm{Aa}$ \\
\hline & 12 & $27.69 \pm 1.03 \mathrm{Ba}$ & $25.97 \pm 0.21 \mathrm{Aa}$ & $25.34 \pm 0.16^{\mathrm{Aa}}$ & $21.00 \pm 1.06^{\mathrm{Aa}}$ \\
\hline \multirow{5}{*}{ SCG } & 0 & $28.14 \pm 2.39 \mathrm{Aa}$ & $25.03 \pm 0.75^{\mathrm{Ba}}$ & $24.47 \pm 1.32 \mathrm{Ab}$ & $22.36 \pm 2.34 \mathrm{Aa}$ \\
\hline & 3 & $28.98 \pm 0.55^{\mathrm{Aa}}$ & $25.25 \pm 0.32 \mathrm{Aa}$ & $24.92 \pm 0.29$ Aab & $20.85 \pm 0.26 \mathrm{Aa}$ \\
\hline & 6 & $27.74 \pm 1.19 \mathrm{Aa}$ & $24.82 \pm 0.31$ Ва & $25.89 \pm 0.15 \mathrm{Aa}$ & $21.55 \pm 0.99 \mathrm{Aa}$ \\
\hline & 9 & $29.12 \pm 0.62 \mathrm{Aa}$ & $24.66 \pm 0.48^{\mathrm{Ba}}$ & $25.65 \pm 0.47 \mathrm{Aa}$ & $20.56 \pm 0.49 \mathrm{Ba}$ \\
\hline & 12 & $29.03 \pm 0.38 \mathrm{Aa}$ & $25.17 \pm 0.40^{\mathrm{Ba}}$ & $25.13 \pm 0.31 \mathrm{Aab}$ & $20.67 \pm 0.52 \mathrm{Aa}$ \\
\hline
\end{tabular}

Uppercase letters indicate significant difference $(p<0.05)$ between different heating processes, lowercase letters indicate the difference between gels with different starch content $(p<0.05)$, and values are expressed as mean \pm SD. 
(a)

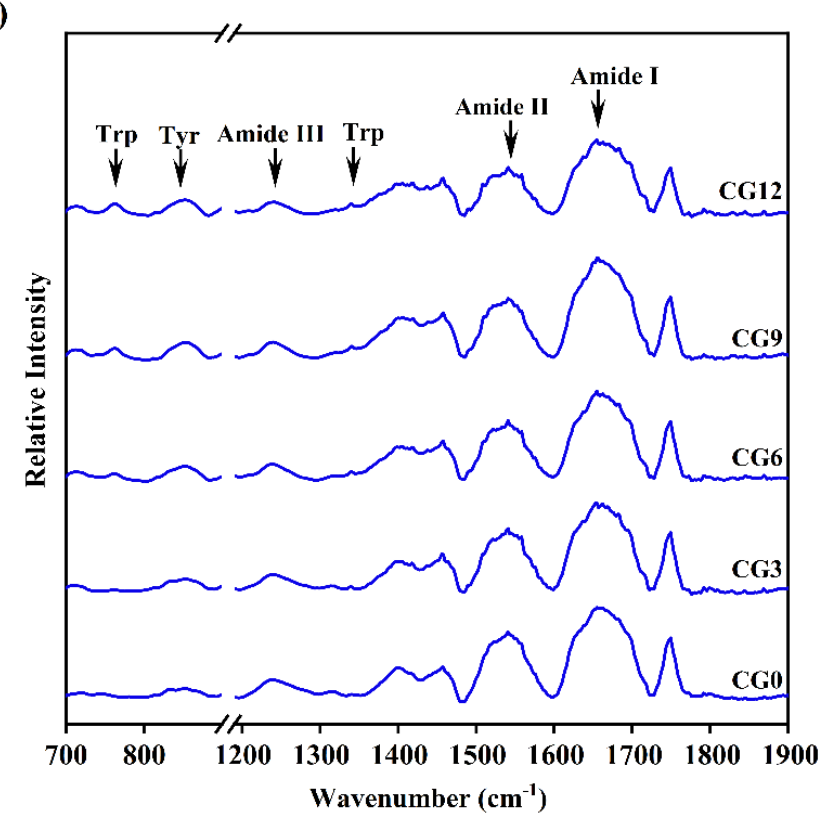

(c)

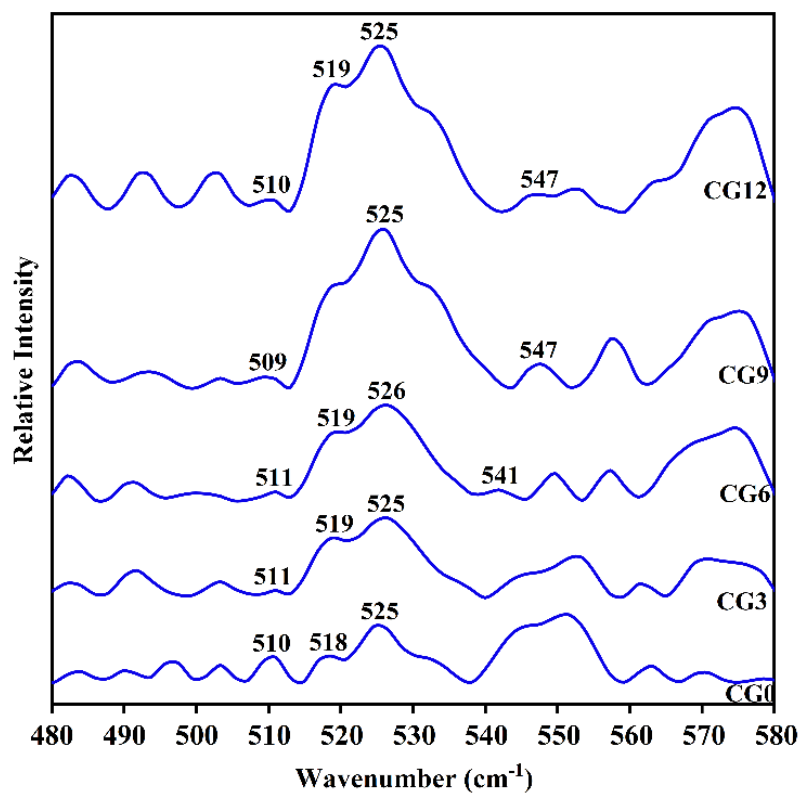

(b)

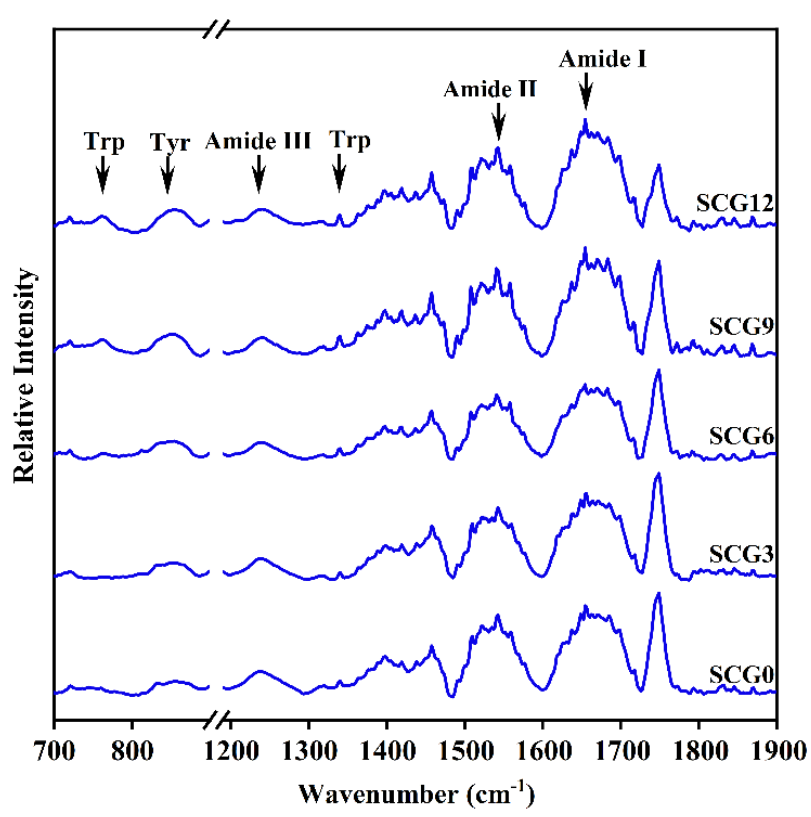

(d)

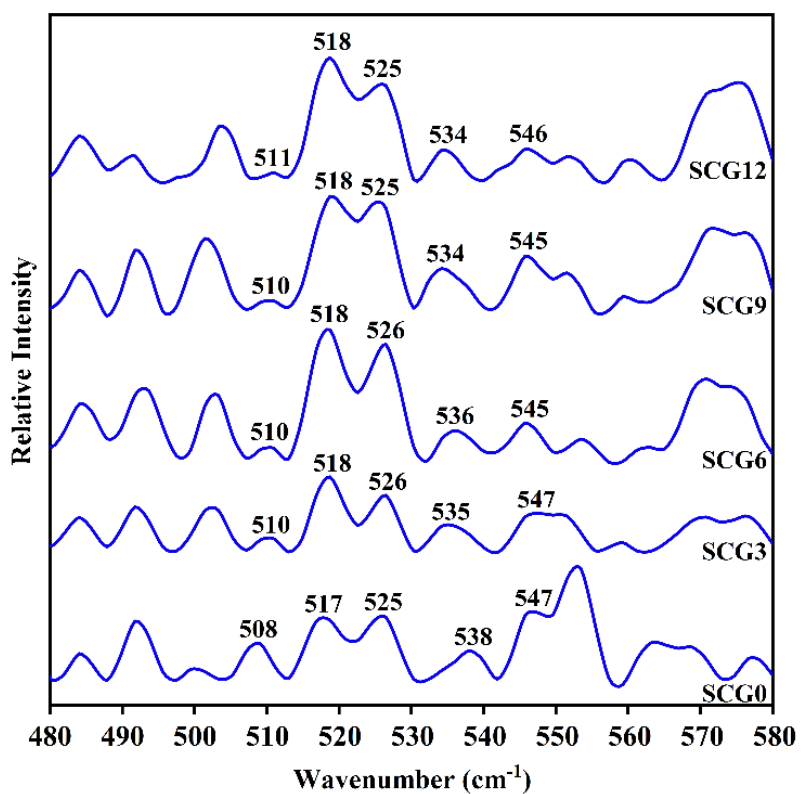

Figure 5. FT-IR spectroscopy $(\mathbf{a}, \mathbf{b})$ and sulfhydryl and disulfides $(\mathbf{c}, \mathbf{d})$ regions of starch-surimi matrix with different treatment. CG0-CG12: cooking gels with starch content (0-12\%); SCG0-SCG12: setting-cooking gels with starch content $(0-12 \%)$.

\subsubsection{Tryptophan (Trp) Residue Bands and Tyrosine (Tyr) Doublet Bands}

The vibrations near 760 and $1340 \mathrm{~cm}^{-1}$ present the microenvironment of Trp residues. Once the Trp residues buried in the hydrophobic environment were exposed to a polar environment, the intensity of bands showed upward trends [41]. The intensity of tryptophan residue bands increased slightly with the increment of starch content in Figure 4 possibly contributing to the exposure of Trp residues [42]. The starch granules occupied the matrix space, which promoted the unfolding of protein structure and then provided impetus to the exposure of the hydrophobic core. A similar result was found in the Tyr doublet bands, which were proposed as a means for determining whether the tyrosine residue was solvent-exposed or buried [43]. If the intensity at $850 \mathrm{~cm}^{-1}\left(\mathrm{I}_{850}\right)$ was higher than $\mathrm{I}_{830}$, this indicated that the Tyr residues at this time changed from the "buried" to the "exposed" state [44]. The distinct vibrations were exhibited differently at 830 and $850 \mathrm{~cm}^{-1}$ in both 
gels (Figure $5 \mathrm{a}, \mathrm{b}$ ). A decreased $\mathrm{I}_{830}$ and a concurrent increased $\mathrm{I}_{850}$ indicated that there were weak hydrophobic interactions among tyrosine residues. It could be demonstrated that protein solubility of CG increased due to reduced hydrophobic interactions. However, the change of hydrophobic amino acids between CG and SCG was not obvious. Therefore, the setting treatment of surimi did not hinder the effect of starch addition on the spatial structure of hydrophobic amino acids in surimi proteins.

\subsubsection{S-S Stretching}

The formation and interchange reactions of disulfide are important for non-reversible heat gelation [9]. Moreover, spectral features in the $500-550 \mathrm{~cm}^{-1}$ region were correlated with the structural parameters of the disulfide bands (Figure 5c, d). Stretching vibrations located at $510 \mathrm{~cm}^{-1}, 516-530 \mathrm{~cm}^{-1}$, and $535-545 \mathrm{~cm}^{-1}$ have been assigned to gauchegauche-gauche, gauche-gauche-trans, and trans-gauche-trans, where the $-\mathrm{C}-\mathrm{S}-\mathrm{S}-\mathrm{C}-$ torsion angle of $90^{\circ}$ was represented as gauche form and that of $180^{\circ}$ was represented as trans form [45]. Due to its low potential energy, the gauche-gauche-gauche form was presumably the most stable among the others [46]. Quantitative analysis of FT-IR spectroscopy showed stable bands located at $510 \mathrm{~cm}^{-1}$ in CG and SCG and disappeared with the increment of starch addition. The weak bands vibrations of CG significantly increased at $516-530 \mathrm{~cm}^{-1}$. It meant that not only disulfide bond conformation changed from gauche-gauche-gauche to gauche-gauche-trans but also new bonds emerged. The variation was consistent with the decrease in total sulfhydryl groups, indicating that more disulfide bonds formed in CG. Therefore, the conformational shift occurred by a combination with excessive starch, which was conducive to the breaking and reformation of disulfide bonds during the direct heating process. The vibrations rose near $518 \mathrm{~cm}^{-1}$ and $525 \mathrm{~cm}^{-1}$ in SCG, accompanied by a decrease in bonds near $510 \mathrm{~cm}^{-1}$. Thus, the setting effect resulted in micro-changes in the conformation of the disulfide bonds in SCG. In brief, the results showed that the matrix after the setting process had a specific compressive capacity, causing fewer vibrations (S-S) changes.

\subsection{Changes in Gel Properties of Starch-Surimi Gels with Non-Setting or Setting Effect 3.5.1. Texture Profile Analysis}

Texture profile analysis simulates chewing twice to obtain the characteristic parameters of the gel matrix (Table 4) [47]. A significant increase in hardness was observed along with the elevated starch content due to reduced moisture content and starch swelling. The starch-absorbed water and swelled during the thermal processing, which increased pressure on the surimi gel [22]. No significant difference in springiness occurred in CG with the addition of starch $(p>0.05)$. However, springiness decreased along with the addition of starch in SCG. It is speculated that if the surimi gel had better gelling properties, then it would play a dominant role in the mixed matrix. Thus, the reduction in springiness in SCG was attributed to decreased surimi concentration. The improvement of cohesiveness and resilience in CG presumably contributed to granule-swelling of starch. The gelation and swelling of starch granules might cause an increase in hydration, which enabled better compatibility of protein networks and starch [14]. SCG showed reduced cohesiveness and resilience with excessive starch, which could be explained by how excessive expansion in starch granules attenuated the stability of the surimi matrix. Thus, potato starch filling could ameliorate the weak gel matrices by increasing texture properties such as hardness and cohesiveness. Nevertheless, the addition of potato starch increased the hardness of the gels but at the same time reduced springiness and cohesiveness. However, compared with a large content of starch, CG still showed lower textural properties, which was connected with the limited filling capacity of natural potato starch and the poor texture of unsetting surimi gel. 
Table 4. Textural properties of starch-surimi mixtures subjected with different heating processes.

\begin{tabular}{|c|c|c|c|c|c|c|}
\hline Samples & $\begin{array}{c}\text { Starch Content } \\
(\%)\end{array}$ & Hardness (g) & Springiness & Cohesiveness & Resilience & Chewiness (g) \\
\hline \multirow{5}{*}{ CG } & 0 & $476.41 \pm 8.31^{\mathrm{Be}}$ & $0.94 \pm 0.00 \mathrm{Ba}$ & $0.73 \pm 0.00 \mathrm{Be}$ & $0.40 \pm 0.00^{\mathrm{Be}}$ & $325.83 \pm 4.29 \mathrm{Be}$ \\
\hline & 3 & $757.80 \pm 20.71 \mathrm{Bd}$ & $0.95 \pm 0.01 \mathrm{Aa}$ & $0.73 \pm 0.00^{\mathrm{Bd}}$ & $0.42 \pm 0.00^{\mathrm{Bd}}$ & $528.43 \pm 20.04^{\mathrm{Bd}}$ \\
\hline & 6 & $1097.31 \pm 11.53 \mathrm{Bc}$ & $0.96 \pm 0.01 \mathrm{Aa}$ & $0.74 \pm 0.00 \mathrm{Bc}$ & $0.43 \pm 0.00 \mathrm{Bc}$ & $780.30 \pm 2.10^{\mathrm{Bc}}$ \\
\hline & 9 & $1382.00 \pm 17.42^{\mathrm{Bb}}$ & $0.94 \pm 0.02 \mathrm{Aa}$ & $0.75 \pm 0.00^{\mathrm{Bd}}$ & $0.44 \pm 0.00^{\mathrm{Bb}}$ & $983.86 \pm 13.48^{\mathrm{Bb}}$ \\
\hline & 12 & $1559.28 \pm 17.46^{\mathrm{Ba}}$ & $0.91 \pm 0.01 \mathrm{Ab}$ & $0.76 \pm 0.00 \mathrm{Ba}$ & $0.45 \pm 0.00 \mathrm{Ba}$ & $1090.18 \pm 20.44 \mathrm{Ba}$ \\
\hline \multirow{5}{*}{ SCG } & 0 & $868.25 \pm 20.61 \mathrm{Ae}$ & $0.97 \pm 0.00 \mathrm{Aa}$ & $0.85 \pm 0.01^{\mathrm{Aa}}$ & $0.59 \pm 0.00 \mathrm{Aa}$ & $716.50 \pm 18.45^{\mathrm{Ae}}$ \\
\hline & 3 & $1023.91 \pm 17.23 \mathrm{Ad}$ & $0.96 \pm 0.02 \mathrm{Aab}$ & $0.84 \pm 0.00 \mathrm{Ab}$ & $0.57 \pm 0.00 \mathrm{Ab}$ & $826.50 \pm 30.43^{\mathrm{Ad}}$ \\
\hline & 6 & $1301.55 \pm 27.10 \mathrm{Ac}$ & $0.94 \pm 0.00 \mathrm{Abc}$ & $0.82 \pm 0.00 \mathrm{Ac}$ & $0.54 \pm 0.01 \mathrm{Ac}$ & $1005.24 \pm 20.65^{\mathrm{Ac}}$ \\
\hline & 9 & $1595.79 \pm 4.69 \mathrm{Ab}$ & $0.93 \pm 0.01 \mathrm{Ac}$ & $0.81 \pm 0.00 \mathrm{Ad}$ & $0.52 \pm 0.00 \mathrm{Ad}$ & $1200.29 \pm 5.83 \mathrm{Ab}$ \\
\hline & 12 & $1874.12 \pm 26.36 \mathrm{Aa}$ & $0.92 \pm 0.01 \mathrm{Ac}$ & $0.80 \pm 0.00 \mathrm{Ae}$ & $0.51 \pm 0.00 \mathrm{Ae}$ & $1383.62 \pm 26.91 \mathrm{Aa}$ \\
\hline
\end{tabular}

Uppercase letters indicate significant difference $(p<0.05)$ between different heating processes, lowercase letters indicate the difference between gels with different starch content $(p<0.05)$, and values are expressed as mean \pm $\mathrm{SD}$

\subsubsection{Whiteness}

Whiteness is one of the most essential indications of surimi quality. The variation in whiteness is found to be correlated not only to the conformation of the gel network but also to the color of additives [48,49]. As presented in Table 5, significant increases in whiteness were found with starch contained in both two types of gels $(p<0.05)$. Moreover, two-step heated gels showed higher whiteness in different starch content compared with direct heating gels. The differences in two types of gels might be attributed to a restrictive effect on starch swelling. $L^{*}, a^{*}$, and $b^{*}$ values decreased as potato starch content increased and presented significant differences between CG and SCG.

Table 5. Whiteness of starch-surimi mixtures subjected with different heating processes.

\begin{tabular}{|c|c|c|c|c|c|}
\hline Samples & $\begin{array}{c}\text { Starch Content } \\
(\%)\end{array}$ & $\mathbf{L}^{*}$ & $a^{*}$ & $\mathbf{b}^{*}$ & Whiteness \\
\hline \multirow{5}{*}{ CG } & 0 & $77.45 \pm 0.17 \mathrm{Aa}$ & $-0.54 \pm 0.12 \mathrm{Aa}$ & $6.06 \pm 0.35^{\mathrm{Aa}}$ & $76.64 \pm 0.14^{\mathrm{Ba}}$ \\
\hline & 3 & $75.51 \pm 0.31 \mathrm{Ab}$ & $-0.60 \pm 0.08^{\mathrm{Aa}}$ & $5.77 \pm 0.15^{\mathrm{Ab}}$ & $74.83 \pm 0.28^{\mathrm{Bb}}$ \\
\hline & 6 & $73.95 \pm 0.39 \mathrm{Bc}$ & $-0.73 \pm 0.05^{\mathrm{Ab}}$ & $5.63 \pm 0.17^{\mathrm{Ab}}$ & $73.33 \pm 0.36^{\mathrm{Bc}}$ \\
\hline & 9 & $71.65 \pm 0.17^{\mathrm{Bd}}$ & $-1.02 \pm 0.08 \mathrm{Ac}$ & $4.96 \pm 0.18$ Ac & $71.20 \pm 0.19^{\mathrm{Bd}}$ \\
\hline & 12 & $71.06 \pm 0.28^{\mathrm{Be}}$ & $-1.06 \pm 0.05^{\mathrm{Ac}}$ & $4.67 \pm 0.06^{\mathrm{Ad}}$ & $70.67 \pm 0.27^{\text {Be }}$ \\
\hline \multirow{5}{*}{ SCG } & 0 & $77.46 \pm 0.24 \mathrm{Aa}$ & $-0.83 \pm 0.06^{\mathrm{Ba}}$ & $5.19 \pm 0.16^{\mathrm{Ba}}$ & $76.86 \pm 0.25 \mathrm{Aa}$ \\
\hline & 3 & $75.77 \pm 0.35^{\mathrm{Ab}}$ & $-0.88 \pm 0.04^{\mathrm{Bb}}$ & $4.92 \pm 0.22 \mathrm{Bb}$ & $75.26 \pm 0.31 \mathrm{Ab}$ \\
\hline & 6 & $74.87 \pm 0.33^{\mathrm{Ac}}$ & $-0.97 \pm 0.05^{\mathrm{Bc}}$ & $4.79 \pm 0.14^{\mathrm{Bb}}$ & $74.40 \pm 0.34^{\mathrm{Ac}}$ \\
\hline & 9 & $73.32 \pm 0.24 \mathrm{Ad}$ & $-1.07 \pm 0.05^{\mathrm{Bd}}$ & $4.46 \pm 0.20^{\mathrm{Bc}}$ & $72.93 \pm 0.21 \mathrm{Ad}$ \\
\hline & 12 & $71.84 \pm 0.21 \mathrm{Ae}$ & $-1.28 \pm 0.04^{\mathrm{Be}}$ & $4.07 \pm 0.06^{\mathrm{Bd}}$ & $71.51 \pm 0.21 \mathrm{Ae}$ \\
\hline
\end{tabular}

Uppercase letters indicate significant difference $(p<0.05)$ between different heating processes, lowercase letters indicate the difference between gels with different starch content $(p<0.05)$, and values are expressed as mean \pm SD. L *: lightness; $a$ *: red-green value; $b$ *: yellow-bule value.

\subsubsection{Water Holding Capacity}

WHC represents the stability of the mixed matrix suffering external forces, which indirectly reflects the compactness of surimi gels and water absorption capacity of starch [50]. As shown in Figure 6, the gel matrix presented a significant increase in WHC accompanied by adding starch in both heating processes $(p<0.05)$. This was in line with previous research by Mi et al. [17] and Luo et al. [14]. It has been revealed that starch had strong hydrophilicity and showed an effective swelling effect with larger particles, which increases the WHC of the gel matrix. The setting effect promoted the formation of the myofibrillar protein network, which could also reduce water loss caused by an external force, thereby increasing WHC. The matrix treated by direct heating showed better WHC with a continuous increase 
in starch content. It was related to the irregular expansion of starch confirmed by the microstructure (Figure 4). In addition, WHC was markedly correlated with the variations in peak area proportion and peak relaxation time [51]. Some possible assumptions could be introduced to describe the changes of WHC: (i) the increase in WHC was associated with the migration of free water by adding starch; (ii) starch showed better swelling states in CG on account of the higher $\mathrm{T}_{\mathrm{P} 2 \mathrm{~b}}$ and lower $\mathrm{T}_{\mathrm{P} 22}$; and (iii) the setting effect improved the stability of immobile water, whereas it limited starch swelling.

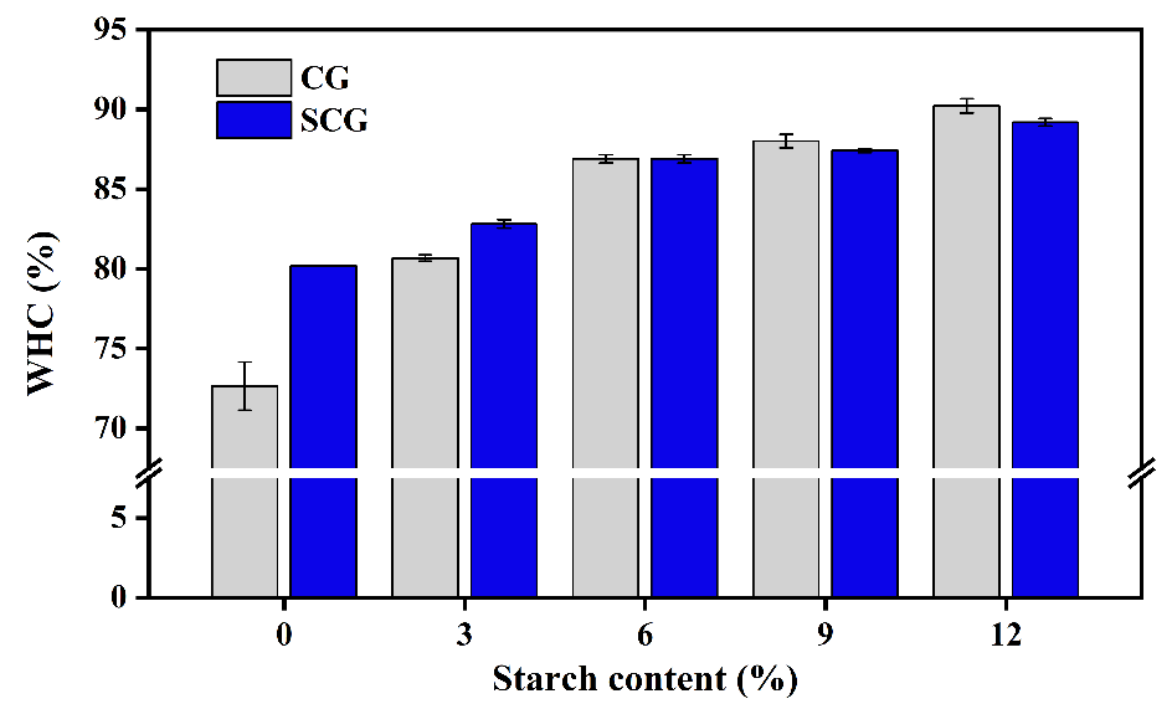

Figure 6. Water holding capacity of different water in starch-surimi matrix subjected to direct heating and two-step heating. Caption: see Figure 1.

\section{Conclusions}

Changes in the water migration and distribution, tissue microstructures, chemical interactions, protein spatial structure, and physical properties were studied. The addition of starch expanded and caused moisture migration, which was ascribed to the combination of free water and hydrophilic groups in starch. The competition between surimi and starch for water affected the chemical interactions and forces in surimi gel components, thereby indirectly resulting in changes in the microstructure and water holding properties of the gel matrix. For the direct cooking matrix, the porous surimi gel lost water when it was squeezed by starch, resulting in a reduction in pore size and immobile water inside. Moreover, starch was not conducive to the interactions of hydrophobic groups, whereas weak disulfide bonds were generated after adding starch. The enhancement of textural properties might be related to changes in protein structure. Subjected to the setting process, the matrix showed an ascendant trend in non-specific associations, ionic bonds, and hydrogen bonds, which was similar to non-setting gels. Setting-cooking gels with a compact structure were less affected by starch-swelling. However, adding excessive starch destroyed the integrity of SCG and decreased cohesiveness and resilience. Therefore, this study found that the addition of starch content had a better supporting effect on weak gels, which provided some insights for improving the quality of surimi-based products. Moreover, further studies are needed to improve the compatibility and active filling of starch in the two-step heating process.

Author Contributions: Conceptualization, X.J.; methodology, X.J. and N.X.; validation, N.X.; formal analysis, X.J., Q.C., and N.X.; investigation, X.J., Y.D., and Q.F.; resources, X.J., Q.C., and Y.D.; data curation, X.J. and Q.C.; writing—original draft, X.J.; writing—review and editing, Q.C., N.X., Y.D., and Q.F.; visualization, X.J.; supervision, W.S.; project administration, W.S.; funding acquisition, W.S. All authors have read and agreed to the published version of the manuscript. 
Funding: This research was funded by the National Key R\&D Program of China, grant number 2019YFD0902003

Institutional Review Board Statement: Not applicable.

Informed Consent Statement: Informed consent was obtained from all subjects involved in the study.

Data Availability Statement: Not applicable.

Conflicts of Interest: The authors declare no conflict of interest.

\section{References}

1. Hou, S.-W.; Wei, W.; Wang, Y.; Gan, J.-H.; Lu, Y.; Tao, N.-P.; Wang, X.-C.; Liu, Y.; Xu, C.-H. Integrated recognition and quantitative detection of starch in surimi by infrared spectroscopy and spectroscopic imaging. Spectrochim. Acta Part A Mol. Biomol. Spectrosc. 2019, 215, 1-8. [CrossRef] [PubMed]

2. Park, J.W.; Lin, T.M.; Yongsawatdigul, J. New developments in manufacturing of Surimi and Surimi seafood. Food Rev. Int. 1997, 13, 577-610. [CrossRef]

3. Arfat, Y.A.; Benjakul, S. Gelling characteristics of surimi from yellow stripe trevally (Selaroides leptolepis). Int. Aquat. Res. 2012, 4, 5 . [CrossRef]

4. Weng, W.; Zheng, W. Silver Carp (Hypophthalmichthys molitrix) Surimi Acid-Induced Gel Extract Characteristics: A Comparison with Heat-Induced Gel. Int. J. Food Prop. 2015, 18, 821-832. [CrossRef]

5. Alipour, H.J.; Rezaei, M.; Shabanpour, B.; Tabarsa, M. Effects of sulfated polysaccharides from green alga Ulva intestinalis on physicochemical properties and microstructure of silver carp surimi. Food Hydrocoll. 2018, 74, 87-96. [CrossRef]

6. Fang, M.; Xiong, S.; Hu, Y.; Yin, T.; You, J. In vitro pepsin digestion of silver carp (Hypophthalmichthys molitrix) surimi gels after cross-linking by Microbial Transglutaminase (MTGase). Food Hydrocoll. 2019, 95, 152-160. [CrossRef]

7. Matsuoka, Y.; Wan, J.; Ushio, H.; Watabe, S. Thermal gelation properties of white croaker, walleye pollack and deepsea bonefish surimi after suwari treatment at various temperatures. Fish. Sci. 2013, 79, 715-724. [CrossRef]

8. Yasui, T.; Ishioroshi, M.; Samejima, K. Effect of Actomyosin on Heat-induced Gelation of Myosin. Agric. Biol. Chem. 1982, 46, 1049-1059. [CrossRef]

9. Liu, R.; Zhao, S.-M.; Xie, B.-J.; Xiong, S.-B. Contribution of protein conformation and intermolecular bonds to fish and pork gelation properties. Food Hydrocoll. 2011, 25, 898-906. [CrossRef]

10. Jia, R.; Jiang, Q.; Kanda, M.; Tokiwa, J.; Nakazawa, N.; Osako, K.; Okazaki, E. Effects of heating processes on changes in ice crystal formation, water holding capacity, and physical properties of surimi gels during frozen storage. Food Hydrocoll. 2019, 90, 254-265. [CrossRef]

11. Luo, Y.; Shen, H.; Pan, D.; Bu, G. Gel properties of surimi from silver carp (Hypophthalmichthys molitrix) as affected by heat treatment and soy protein isolate. Food Hydrocoll. 2008, 22, 1513-1519. [CrossRef]

12. Chen, H.; Zou, Y.; Zhou, A.; Xiao, J.; Benjakul, S. Insight into the Effect of Ice Addition on the Gel Properties of Nemipterus virgatus Surimi Gel Combined with Water Migration. Foods 2021, 10, 1815. [CrossRef]

13. Watabe, S.; Ikeda, D.; Mashiro, T.; Kagetakubo, Y.; Takahashi, Y.; Uemura, M.; Mizusawa, N.; Koyama, H.; Yasumoto, K.; Jimbo, M.; et al. Suitability of Japanese codling as a raw material for surimi-based products revealed by primary sequence analysis of myosin heavy chain and thermal gel properties. Fish. Sci. 2020, 86, 711-719. [CrossRef]

14. Luo, H.; Guo, C.; Lin, L.; Si, Y.; Gao, X.; Xu, D.; Jia, R.; Yang, W. Combined Use of Rheology, LF-NMR, and MRI for Characterizing the Gel Properties of Hairtail Surimi with Potato Starch. Food Bioprocess Technol. 2020, 13, 637-647. [CrossRef]

15. Jia, R.; Katano, T.; Yoshimoto, Y.; Gao, Y.; Watanabe, Y.; Nakazawa, N.; Osako, K.; Okazaki, E. Sweet potato starch with low pasting temperature to improve the gelling quality of surimi gels after freezing. Food Hydrocoll. 2018, 81, 467-473. [CrossRef]

16. Kong, C.; Ogawa, H.; Iso, N. Temperature Dependency of Compression Properties of Fish-meat Gel as Affected by Added Starch. J. Food Sci. 1999, 64, 1048-1051. [CrossRef]

17. Mi, H.; Wang, C.; Su, Q.; Li, X.; Yi, S.; Li, J. The effect of modified starches on the gel properties and protein conformation of Nemipterus virgatus surimi. J. Texture Stud. 2019, 50, 571-581. [CrossRef] [PubMed]

18. Sun, F.; Huang, Q.; Hu, T.; Xiong, S.; Zhao, S. Effects and mechanism of modified starches on the gel properties of myofibrillar protein from grass carp. Int. J. Biol. Macromol. 2014, 64, 17-24. [CrossRef] [PubMed]

19. Yang, Z.; Wang, W.; Wang, H.; Ye, Q. Effects of a highly resistant rice starch and pre-incubation temperatures on the physicochemical properties of surimi gel from grass carp (Ctenopharyn Odon Idellus). Food Chem. 2014, 145, 212-219. [CrossRef]

20. Pan, T.; Guo, H.; Li, Y.; Song, J.; Ren, F. The effects of calcium chloride on the gel properties of porcine myosin-k-carrageenan mixtures. Food Hydrocoll. 2017, 63, 467-477. [CrossRef]

21. Zhang, H.; She, W.; Li, L.; Wang, W. Effect of temperature rising inhibitor on autogenous shrinkage of cement pastes. Constr. Build. Mater. 2019, 220, 329-339. [CrossRef]

22. Jia, R.; Katano, T.; Yoshimoto, Y.; Gao, Y.; Nakazawa, N.; Osako, K.; Okazaki, E. Effect of small granules in potato starch and wheat starch on quality changes of direct heated surimi gels after freezing. Food Hydrocoll. 2020, 104, 105732. [CrossRef] 
23. Yan, B.; Jiao, X.; Zhu, H.; Wang, Q.; Huang, J.; Zhao, J.; Cao, H.; Zhou, W.; Zhang, W.; Ye, W.; et al. Chemical interactions involved in microwave heat-induced surimi gel fortified with fish oil and its formation mechanism. Food Hydrocoll. 2020, 105, 105779. [CrossRef]

24. Reichardt, W.; Eckert, B. Zur Bestimmung des Proteingehaltes von Milch, Käse und Fleisch mit Hilfe der Biuret-Reaktion. Food/Nahrung 1991, 35, 731-738. [CrossRef] [PubMed]

25. Zhang, L.; Li, Q.; Shi, J.; Zhu, B.; Luo, Y. Changes in chemical interactions and gel properties of heat-induced surimi gels from silver carp ( Hypophthalmichthys molitrix ) fillets during setting and heating: Effects of different washing solutions. Food Hydrocoll. 2018, 75, 116-124. [CrossRef]

26. Singh, A.; Benjakul, S.; Prodpran, T.; Nuthong, P. Effect of Psyllium (Plantago ovata Forks) Husk on Characteristics, Rheological and Textural Properties of Threadfin Bream Surimi Gel. Foods 2021, 10, 1181. [CrossRef] [PubMed]

27. Zhang, Z.; Regenstein, J.M.; Zhou, P.; Yang, Y. Effects of high intensity ultrasound modification on physicochemical property and water in myofibrillar protein gel. Ultrason. Sonochem. 2017, 34, 960-967. [CrossRef] [PubMed]

28. Li, X.; Fan, M.; Huang, Q.; Zhao, S.; Xiong, S.; Yin, T.; Zhang, B. Effect of micro- and nano-starch on the gel properties, microstructure and water mobility of myofibrillar protein from grass carp. Food Chem. 2022, 366, 130579. [CrossRef] [PubMed]

29. Fang, Q.; Shi, L.; Ren, Z.; Hao, G.; Chen, J.; Weng, W. Effects of emulsified lard and TGase on gel properties of threadfin bream (Nemipterus virgatus) surimi. LWT 2021, 146, 111513. [CrossRef]

30. Kim, J.M.; Lee, C.M.; Hufnagel, L.A. Textural properties and structure of starch-reinforced surimi gels as affected by heat-setting. Food Struct. 1987, 6, 81-89.

31. Stone, A.; Stanley, D. Mechanisms of fish muscle gelation. Food Res. Int. 1992, 25, 381-388. [CrossRef]

32. Liu, Y.; Sun, Q.; Wei, S.; Xia, Q.; Pan, Y.; Ji, H.; Deng, C.; Hao, J.; Liu, S. Insight into the correlations among rheological behaviour, protein molecular structure and 3D printability during the processing of surimi from golden pompano (Trachinotus ovatus). Food Chem. 2022, 371, 131046. [CrossRef]

33. Jia, D.; Huang, Q.; Xiong, S. Chemical interactions and gel properties of black carp actomyosin affected by MTGase and their relationships. Food Chem. 2016, 196, 1180-1187. [CrossRef]

34. Li, Z.; Wang, J.; Zheng, B.; Guo, Z. Effects of high pressure processing on gelation properties and molecular forces of myosin containing deacetylated konjac glucomannan. Food Chem. 2019, 291, 117-125. [CrossRef] [PubMed]

35. Liu, H.; Gao, L.; Ren, Y.; Zhao, Q. Chemical Interactions and Protein Conformation Changes During Silver Carp (Hypophthalmichthys molitrix) Surimi Gel Formation. Int. J. Food Prop. 2014, 17, 1702-1713. [CrossRef]

36. Cao, H.; Fan, D.; Jiao, X.; Huang, J.; Zhao, J.; Yan, B.; Zhou, W.; Zhang, W.; Zhang, H. Effects of microwave combined with conduction heating on surimi quality and morphology. J. Food Eng. 2018, 228, 1-11. [CrossRef]

37. Chen, Y.; Xu, A.; Yang, R.; Jia, R.; Zhang, J.; Xu, D.; Yang, W. Chemical interactions and rheological properties of hairtail (Trichiurus haumela) surimi: Effects of chopping and pressure. Food Biosci. 2020, 38, 100781. [CrossRef]

38. Yu, W.; Wang, Z.; Pan, Y.; Jiang, P.; Pan, J.; Yu, C.; Dong, X. Effect of k-carrageenan on quality improvement of 3D printed Hypophthalmichthys molitrix-sea cucumber compound surimi product. LWT 2021, 154, 112279. [CrossRef]

39. Fevzioglu, M.; Ozturk, O.K.; Hamaker, B.R.; Campanella, O.H. Quantitative approach to study secondary structure of proteins by FT-IR spectroscopy, using a model wheat gluten system. Int. J. Biol. Macromol. 2020, 164, 2753-2760. [CrossRef] [PubMed]

40. Zhuang, X.; Jiang, X.; Zhou, H.; Chen, Y.; Zhao, Y.; Yang, H.; Zhou, G. Insight into the mechanism of physicochemical influence by three polysaccharides on myofibrillar protein gelation. Carbohydr. Polym. 2020, 229, 115449. [CrossRef] [PubMed]

41. Wang, L.; Xia, M.; Zhou, Y.; Wang, X.; Ma, J.; Xiong, G.; Wang, L.; Wang, S.; Sun, W. Gel properties of grass carp myofibrillar protein modified by low-frequency magnetic field during two-stage water bath heating. Food Hydrocoll. 2020, 107, 105920. [CrossRef]

42. Sun, W.; Zhao, Q.; Zhao, M.; Yang, B.; Cui, C.; Ren, J. Structural Evaluation of Myofibrillar Proteins during Processing of Cantonese Sausage by Raman Spectroscopy. J. Agric. Food Chem. 2011, 59, 11070-11077. [CrossRef]

43. Herrero, A.; Carmona, P.; Cofrades, S.; Jimenez-Colmenero, F. Raman spectroscopic determination of structural changes in meat batters upon soy protein addition and heat treatment. Food Res. Int. 2008, 41, 765-772. [CrossRef]

44. Yu, D.; Zhang, X.; Zou, W.; Tang, H.; Yang, F.; Wang, L.; Elfalleh, W. Raman spectroscopy analysis of the effect of electrolysis treatment on the structure of soy protein isolate. J. Food Meas. Charact. 2021, 15, 1294-1300. [CrossRef]

45. Podstawka, E.; Ozaki, Y.; Proniewicz, L.M. Adsorption of S-S Containing Proteins on a Colloidal Silver Surface Studied by Surface-Enhanced Raman Spectroscopy. Appl. Spectrosc. 2004, 58, 1147-1156. [CrossRef]

46. Pfeuti, G.; Brown, L.S.; Longstaffe, J.G.; Peyronel, F.; Bureau, D.P.; Kiarie, E.G. Predicting the standardized ileal digestibility of crude protein in feather meal fed to broiler chickens using a pH-stat and a FT-Raman method. Anim. Feed. Sci. Technol. 2020, 261, 114340. [CrossRef]

47. Bourne, M.C. Food Texture and Viscosity: Concept and Measurement, 2nd ed.; Academic Press: Salt Lake City, UT, USA, 2002; pp. 182-186.

48. Petcharat, T.; Benjakul, S. Effect of gellan incorporation on gel properties of bigeye snapper surimi. Food Hydrocoll. 2018, 77, 746-753. [CrossRef]

49. Uresti, R.M.; Velazquez, G.; Ramírez, J.A.; Vázquez, M.; Torres, J.A. Effect of high-pressure treatments on mechanical and functional properties of restructured products from arrowtooth flounder (Atheresthes stomias). J. Sci. Food Agric. 2004, 84, 1741-1749. [CrossRef] 
50. Dong, X.; Huang, Y.; Pan, Y.; Wang, K.; Prakash, S.; Zhu, B. Investigation of sweet potato starch as a structural enhancer for three-dimensional printing of Scomberomorus niphonius surimi. J. Texture Stud. 2019, 50, 316-324. [CrossRef]

51. Duflot, M.; Sánchez-Alonso, I.; Duflos, G.; Careche, M. LF $1 \mathrm{H}$ NMR T2 relaxation rate as affected by water addition, $\mathrm{NaCl}$ and $\mathrm{pH}$ in fresh, frozen and cooked minced hake. Food Chem. 2019, 277, 229-237. [CrossRef] [PubMed] 